\title{
Equilibrium
}

Quarterly Journal of Economics and Economic Policy

VOLUME 7 ISSUE 3, 2012

ISSN $1689-765 \mathrm{X}$

\author{
Andrzej Cieślik, Jan Jakub Michałek, \\ Jerzy Mycielski* \\ University of Warsaw, Poland
}

\section{Euro AND Trade Flows \\ in Central Europe}

JEL Classification Codes: $F 1, F 15$, E5

Keywords: Central Europe, exports, euro, volume of trade

\begin{abstract}
In this paper we estimate the trade effects of the euro adoption in Central European countries using a modified gravity model. In particular, we analyze the ex post implications of accession of Slovenia and Slovakia to the Eurozone. We employ a gravity model that controls for an extended set of trade theory and policy variables. Trade theory variables include both the country size and factor proportion variables. Trade policy variables include the membership in GATT/WTO, CEFTA, $O E C D, E U$ and Europe Agreements. The gravity model is estimated using the panel data approach on a sample of CEE countries trading with the rest of the world during the period 1992-2009 using the fixed effects, random effects and HausmanTaylor estimators. It seems that elimination of exchange rate volatility resulted in trade expansion for the CEE countries but the accession to the Eurozone did not have any significant effects on exports of Slovakia and Slovenia.
\end{abstract}

\section{INTRODUCTION}

The impact of the adoption of a common currency on international trade flows has been one of the most hotly debated issues in international econom-

(C) Copyright Nicolaus Copernicus University Press

Date of Submission: February 26, 2011; date of acceptance: June 30, 2012

* Contact: e-mail: michalek@wne.uw.edu.pl, Uniwersytet Warszawski, Wydział Nauk Ekonomicznych, ul. Długa 44/50, 00-241 Warszawa, Poland 
ics. It has been frequently argued that the elimination of the exchange rate risk will stimulate exports of existing firms and encourage non-exporters that previously limited their operations to their domestic markets only to start exporting (Baldwin et al., 2005). This effect is perceived to be especially important for countries where forward foreign exchange markets are not very well developed. Moreover, a reduction of the transaction cost associated with elimination of the exchange rate risk is argued to be important for countries that are characterized by the strong concentration of their trade with one large trading partner or a group of countries that share a common currency. This is the case for many Central and Eastern European (CEE) countries for which Germany is the main trading partner, and more than 50 per cent of their trade takes place with the members of the Eurozone.

According to the recent empirical studies, the trade among the members of the EMU has grown on average by 10-15\% due to the use of a common currency and there was also an increase in trade with the non-member states. However, these studies did not take into account the latest EMU enlargements and the impact of 2008-2009 world economic crisis. Therefore, the main aim of this paper is to evaluate the ex post effects of two new EU member countries' (Slovakia and Slovenia) accession to the European Economic and Monetary Union (EMU) on their exports. To evaluate these effects we will estimate a generalized gravity model. This study will help in understanding whether and by how much the adoption of the euro will contribute to the development of trade between other Central European countries and the members of the EMU.

In contrast to the previous studies, which were devoted to the evaluation of the effects of the creation of the Eurozone, we study the implications of accession of new Central European countries to the already existing and functioning EMU. In particular, we test empirically the hypothesis that the accession to the Eurozone of two new EU member countries: Slovakia and Slovenia had a similar effect on trade as in the case of the Eurozone founding members. However, it should be kept in mind that the effect of the accession to the already existing monetary union may be different from the effect of the Eurozone foundation by developed old EU members.

In addition, we should take into account the specificity of these countries that still have lower incomes per capita, are less developed and more agricultural than the founding members of the Eurozone. Moreover, the trade structure of Central European countries is different from that of the old Eurozone members. In particular, Slovakia and Slovenia still trade more homogeneous and less differentiated goods than the Eurozone members, which is reflected in much lower share of intra-industry trade in their trade flows despite their rapid increase in the recent years. In contrast to the case of the founding members of the Eurozone we should not expect that the assumption of com- 
plete specialization in production to hold in the case of the Central European countries. Therefore, to underpin our analytical framework we use the extended gravity model that assumes incomplete specialization in production and takes into account the role of factor proportions and technology differences.

Moreover, we focus on the trade policy changes in Central European countries that may affect bilateral trade. Slovakia and Slovenia, since the beginning of their economic transformation in the early 1990s, have drastically liberalized their trade regimes and became the members of the multilateral as well as various regional trading agreements. These include CEFTA, EFTA and, above all, the Europe Agreements that served as an intermediate step towards the full EU membership. The subsequent steps in trade liberalization were often argued to have an important impact on the development of trade in the Central European countries in many previous studies and therefore will be taken into account in this study.

We estimate the gravity model on a sample of CEE countries trading with the rest of the world during the period 1992-2009 using three estimations: fixed effects, random effects and Hausman-Taylor that allow us to exploit the panel properties of the dataset. Our estimation results show that the elimination of exchange rate volatility resulted in trade expansion for the CEE countries, but the accession to the Eurozone did not have any significant effects on exports of both Slovakia and Slovenia.

The structure of this paper is as follows. In the next section we survey the literature on the impact of the euro adoption in the Central European countries. Then we describe the analytical framework and discuss data sources. Finally, we present estimation results on the ex post impact of the euro on trade in Slovakia and Slovenia that have already adopted the common currency. The last section summarizes and concludes.

\section{LITERATURE REVIEW}

The first widely cited attempts to estimate the trade effects of the monetary union were made by Rose $(2000 ; 2001)$ who identified two main effects of the adoption of a common currency: the effects associated with the elimination of the exchange rate volatility and the pure monetary effect associated with the use of a single currency. His early studies yielded very surprising results, suggesting that the participation in the monetary union may increase trade between its member countries even threefold. Since then a number of studies on the potential trade effects of the participation in the monetary union have emerged. Many authors have suggested various reasons for overestimation of trade effects associated with the adoption of a common curren- 
cy, such as a sample selection bias or the endogeneity of the monetary union ${ }^{1}$.

For example, Barr et al. (2003) who studied the potential effects of the EMU for the EU and EFTA countries tried to solve the endogeneity problem by using instrumental variables. A similar study was done by Micco et al. (2003) who focused on the OECD countries. In these studies the predicted trade effects of joining the monetary union were much lower, and especially in the latter amounted only to a 6 per cent increase. An interesting study was conducted also by Flam and Nordstrom (2002) who studied the trade effects of a monetary union separately for various SITC product groups. It turned out that the strongest effects of the monetary union were reported for trade in processed manufactured products, and in particular SITC groups 6-8. More recently, Berger and Nitsch (2008) argue that the euro's impact on trade disappears if the positive trend in the institutional integration is controlled. The comprehensive survey of the early literature on the trade consequences of joining the monetary union has been complied by Baldwin (2006) who suggested the need of controlling individual country effects (as well as multilateral resistance terms).

The trading potential of the Central European countries has been studied by many authors, including Fidrmuc et al. (2001). Very few attempts were made to estimate ex ante trade effects of the euro adoption by these countries. The first such attempt was made by Maliszewska (2004) who studied bilateral trade flows between the EU and the Central European countries during the period 1992-2002. She estimated a simple gravity model by OLS to find that the parameter estimate on the EMU dummy variable was positive and statistically significant. In particular, she found that as a result of the euro adoption trade would increase on average by 23 per cent. Then she used this estimate to make a forecast for the CEE countries, assuming that these countries will reach the same level of trade openness as the EMU members. According to her forecast, as the result of the euro adoption, the less open countries such as Poland, Latvia and Lithuania will experience a significant increase in trade, while already open countries such as the Czech Republic, Estonia and Slovakia will experience a decrease in trade.

However, another study by Belke and Spies (2008) leads to a completely different conclusion. The authors included in their analysis all the OECD and the CEE countries during the period 1992-2004. They estimated a gravity model based on the assumption of the complete specialization using the

\footnotetext{
${ }^{1}$ For example, endogeneity can be associated with central bank policies and colonial ties. In particular, exchange rate volatility may not be exogenous if central banks want to decrease the range of exchange rate fluctuations with respect to the currencies of their main trading partners. The main trading partners for developing countries are often former colonizers with respect to which former colonies stabilize their exchange rates.
} 
Hausman-Taylor approach that allowed them to endogenize the EMU variable. In their study the estimated parameter on the EMU variable also turned out to be positive and statistically significant. However, in contrast to Maliszewska (2004), their forecast showed that relatively closed economies such as Poland, Latvia and Lithuania would experience a decrease in their exports while more open economies such as the Czech Republic, Estonia and Slovakia would experience an increase in their exports.

In a more recent study by Cieślik, Michałek and Mycielski (2009), the authors analyzed the ex ante trade effects of Poland joining the Eurozone using a generalized gravity model. They employed panel data for the present members of the Eurozone and almost 100 other countries trading with the Eurozone countries during the period of 1993-2006. Their forecast consisted of two elements. First, the authors estimated the effect of exchange rate stabilization against the euro, making use of data for the group of Central and Eastern European countries which pegged their currency to the euro. The second component of the forecast was based on the analysis of the impact of joining the Eurozone. It involved the elimination of exchange rate fluctuations effect and the impact of trade policy changes related to joining the Eurozone. Their results suggested that just after joining the Eurozone, Polish exports will increase by ca. 12 per cent, but the positive effect will gradually disappear over time.

Finally, in a related contribution on the effects of the EMU enlargement by Brouwer, Paap and Viaene (2008), the authors studied the impact of the exchange rate volatility on trade and FDI using the fixed effects estimator and unbalanced panel data for 29 countries (the EMU members, the new EU countries, the rest of EU and the four other OECD countries: Canada, Japan, Switzerland and the US) during the period 1980-2005. Although their main results focused on FDI, they report that the direct export effect of joining the EMU for all countries is positive and varied depending on the level of volatility and trade balance from 0.84 per cent for Lithuania to 13.3 per cent for Malta.

The ex post evaluation of trade effects of euro adoption in the Central European countries is virtually non-existent. The only exception is the study by Aristovnik and Meze (2009) who used a time series approach to study the ex post effect of the EMU creation for Slovenian trade. They argued that the trade benefits of the entry of new countries into the EMU would thus not be the same as the benefits of the initial formation of the EMU in the nineties. Their claim has been tested on the example of Slovenia. A regression analysis of time series showed that there had been a positive effect on Slovenia's exports into and a negative effect on its imports from the Eurozone precisely at the time of the creation of the EMU in 1999. However, they did not study the ex post effects of 2006 Slovenia accession to the Eurozone. 


\section{ANALYTICAL FRAMEWORK}

The analytical framework used in this study is based on the generalized gravity equation derived from the trade theory models that assume incomplete specialization in production. In the traditional gravity models trade flows are explained by the economic size of the trading partners and the distance between them. As argued in the introduction such models are not appropriate for explaining the pattern of trade of the Central European countries, as they assume complete specialization in production. Therefore, in our specification, in addition to the standard gravity variables, we will also use the measures of relative factor endowments (Bergstrand (1990), Cieślik (2009)). Moreover, we will also focus on changes in trade policy which occurred during the period covered by our sample and which reflect multilateral as well as regional trade liberalization. Our estimating equation used to study the determinants of bilateral trade flows, specified in the logarithmic form, is as follows:

$$
\begin{aligned}
& \ln T_{i j t}=\alpha_{0}+\alpha_{1} \ln Y_{i t}+\alpha_{2} \ln Y_{j t}+\alpha_{3} \ln \text { land }_{i t}+\alpha_{4} \ln \text { land }_{j t}+\alpha_{5} \ln \text { Dist }_{i j}+\alpha_{6} E M U_{i j t} \\
& +\alpha_{7} E R M 2_{i j t}+\alpha_{8} C P E M U_{i j t}+\alpha_{9} \ln \text { Exchange }{ }_{-} s d_{i j t}+\xi^{\prime} Z_{i j t}+c_{i j}+\theta_{t}+\varepsilon_{i j t}
\end{aligned}
$$

where:

$T_{i j t}$ : bilateral exports or the volume of trade (exports plus imports) between country $i$ and $j$ in year $t$ depending on model specification;

$Y_{i t}:$ GDP in country $i$ in year t;

land $_{i t}$ : arable land per capita in country $i$ in year t;

$Y_{j t}:$ GDP in country $j$ in year $\mathrm{t}$;

land $_{j t}$ : arable land per capita in country $j$ in year $\mathrm{t}$;

Dist $_{i j}$ : distance between country $i$ and $j$;

$E M U_{i j t}$ : dummy variable that takes value 1 if both countries are the members of the European Monetary Union in year $t$ and 0 otherwise;

$E R M 2_{i j t}$ : dummy variable that takes value 1 if both countries are the members of ERM2 in year $\mathrm{t}$ and 0 otherwise;

CPEMU $U_{i j t}$ : (Central_pegged_to_EMU): dummy variable that takes value 1 if both countries decided to stabilize their exchange rates but pegging their national currencies to the euro in year $t$ and 0 otherwise;

Exchange_sd $d_{i j t}$ : exchange rate volatility between country $i$ and country $j$ in year t; $Z_{i j t}$ : vector of other explanatory variables that may affect bilateral trade between country $i$ and country $j$ in year t (such as WTO and OECD membership, regional 
trading agreements and customs unions, historical ties, geographic location: contiguity, landlocked). The complete list of variables is presented below;

$c_{i j}$ : individual country-pair specific effect that may be fixed or random depending on model specification;

$\theta_{t}$ : random, not observable time specific effect in the period $t$, affecting all observations in the same way;

$\varepsilon_{i j t}$ : error term, which is assumed to be not be correlated with $c_{i j}$ and $\theta_{t}$, homoscedastic not autocorrelated.

In addition to the standard set of gravity variables in our equation we used a set of control variables, which include economic geography and historical ties variables as well as trade policy variables. Economic geography variables include contiguity and landlocked location. Contiguity may stimulate cross-border trade, while landlocked location may discourage trade due to lack of sea access. Moreover, many former French colonies pegged their currencies to the euro ( previously the French franc) to facilitate trade. Therefore, taking into account this fact, we added an extra variable. Furthermore, communist past may affect trade of Central European countries. We speculate that trade in Central European countries might have been below the potential level because those countries were relatively closed under the communist regime.

Trade policy variables include various institutional arrangements facilitating development of international trade at the global or regional scale. World trade facilitating arrangements include GATT/WTO and OECD memberships. The main regional agreement affecting trade is the European Union. In addition to this, we also included the variables describing participation in free trade areas concluded by Central European countries among themselves (CEFTA) and with the EU (Europe Agreements). These agreements can be seen as intermediate steps preceding full EU membership. The aim of these agreements was to gradually liberalize trade and approximate legislation of Central European countries to EU standards.

Economic geography variables:

- contig $_{i j t}$ : dummy variable that takes value 1 if there is a common border between countries $i$ and $j$ in year $t$ and 0 otherwise;

- repl_locked $d_{i}$ : dummy variable indicating whether reporter country has the access to the sea;

- partl_locked $_{j}$ : dummy variable indicating whether partner country has the access to the sea. 
Historical ties variables:

- Africa_EMU $U_{i t}$ : dummy variable that takes value 1 if a non-European (African) pegged its exchange rate to the euro in year $t$ and 0 otherwise;

- part_CentralEurope $e_{j}$ : dummy variable that takes value 1 if partner country is the is the Central European country and 0 otherwise.

Trade policy variables:

- GATT_WTO $O_{i j t}$ : dummy variable indicating whether in year $t$ both countries are the GATT/WTO members;

- $O E C D_{i j t}$ : dummy variable indicating whether in year $t$ both trading countries are the OECD members;

- $E U_{i j t}$ : dummy variable that takes value 1 if both countries are the members of the European Union in year $\mathrm{t}$ and 0 otherwise;

- Europe_Agrmt ijt: dummy variable that takes value 1 if CEE country was the member of the European Agreement in year $t$ with the European Union and 0 otherwise;

- CEFTA ${ }_{i j t}$ (Central Free Trade Area): dummy variable indicating whether both trading countries in year $t$ were the members of the CEFTA.

The generalized gravity equation was estimated employing three different estimation methods: fixed effects, random effects and Hausman-Taylor estimators that allow us to exploit the panel properties of the dataset. The standard panel data techniques including fixed and random effects allow us to take into account individual country pair characteristics, while the HausmanTaylor (H-T) approach allows controlling the potential endogeneity of the key explanatory variables such as: the EMU, the ERM2 and the various forms of pegging the exchange rates of Central European currencies to the euro. Our empirical specification includes an unobserved effect $c_{i}$ that can be often correlated with explanatory variables. In this case the joint error term can be defined as $v_{i j t}=c_{i j}+\varepsilon_{i j t}$. In the case when the individual effect $c_{i}$ is correlated with the explanatory variables, the estimation results will suffer from the simultaneity bias due to the correlation between the individual effects and the explanatory variables. The standard solution to this problem is to use fixed effects (FE) or first differences (FD). The main drawback of the aforementioned approaches is inefficiency of these estimators if some of the explanatory variables are in fact not correlated with the individual effects ${ }^{2}$. Therefore, we refer to an intermediate solution and choose the HausmanTaylor approach as the preferred estimation method. The explanatory variables can be divided into two groups: those that are correlated with $c_{i}$ (endogenous) and those that are not (exogenous). In making our distinction between exogenous and endogenous variables we generally followed the approach proposed by Belke and Spies (2008). This approach assumes that the dummy

${ }^{2}$ Another drawback of this approach is the elimination of the potentially interesting variables which are time invariant, such as distance, from the model. 
variables for a membership in preferential trade and monetary agreements are endogenous variables. The H-T estimator allows us to obtain the estimates for all explanatory variables.

\section{DATA SOURCES}

In our study we used bilateral trade flows of two Central European countries: Slovakia and Slovenia that were treated as reporters, among themselves as well as with all other countries, that were treated as partners, excluding the smallest countries. ${ }^{3}$ The detailed list of partner countries is provided in the appendix. The sample covers the period 1992-2009 which yields around 4.5 thousand observations for the combined sample of two countries. Macroeconomic data were obtained from the World Development Indicators (WDI) published on-line by the World Bank in Washington. Exchange rate data were called from the International Financial Statistics (IFS) 2011 database published on CD-ROM by the International Monetary Fund (IMF). The complete description of the dataset and data sources used in our study is provided below:

- Exports: data expressed in the current US dollars for exports (gross exports). Trade data comes from the WITS (World Integrated Trade Solution) database, compiled jointly by the World Bank, WTO and UNCTAD;

- Exchange_sd $d_{i j t}$ : variable measuring volatility of bilateral exchange rates in the importing and the exporting country. Bilateral exchange rates and their volatility were calculated using data from International Financial Statistics (IFS) database compiled by the International Monetary Fund, where the exchange rates were expressed in relation to the SDR of particular countries at the end of the month. Following earlier studies exchange rate volatility was measured using the standard deviation of first differences of logs. These differences are equal to zero when the exchange rate does not change;

- GDP: GDP variable is measured in current US dollars. GDP data comes from World Development Indicators (WDI) database compiled by the World Bank. GDP variable measures the economic size of trading countries;

- Arable land per capita: Data comes also from the WDI database. Arable land per capita measures differences in factor proportions between trading partners;

\footnotetext{
${ }^{3}$ The smallest economies with the population less than 200 thousand inhabitants were excluded from our sample.
} 
- Dist $i_{i j}$ : Geographic distance between trading countries measured using the great circle formula. Distance variable proxies for trade costs. Data on distance comes from CEPII (Centre d'Etudes Prosepctives et d'Informations Internationales ) database ;

- CONTIG $G_{i j}$ : dummy variable indicating whether both trading countries share a common order;

- OECD: dummy variable indicating whether both trading countries are the OECD members;

- GATT_WTO: dummy variable indicating whether both countries are the GATT/WTO members;

- CEFTA (Central Free Trade Area): dummy variable indicating whether both trading countries are the members of the CEFTA;

- Europe Agreements: dummy variable indicating the existence of the European Agreement between the CEE country and the EU member;

- Central_to_EMU: dummy variable indicating whether the CEE country pegged its exchange rate to the euro;

- Africa_to-EMU: dummy variable indicating whether a non-European (African) country when trading with the EMU member pegged its exchange rate to the euro;

- ERM 2: dummy variable indicating participation in Exchange Rate Mechanism 2;

- EMU: dummy variable indicating whether both trading countries are the members of the EMU.

Landlocked and contiguity data come from CEPII (Centre d'Etudes Prospectives et d'Informations Internationales) data base. Other variables were created by the authors on the basis of publicly available information.

\section{ESTIMATION RESULTS}

Our estimation results were obtained for the full sample for bilateral exports as well as the bilateral exports of two Central European countries: Slovakia and Slovenia. The estimation results for the bilateral exports obtained for the combined sample using three different estimators: the FE, RE and HT estimators are reported in Table 1. 
Table1. Estimation Results for the Combined Sample

(t- and z-stats)

\begin{tabular}{|c|c|c|c|}
\hline $\begin{array}{l}\text { Estimation } \\
\text { method }\end{array}$ & $\begin{array}{c}\mathbf{F E} \\
\mathbf{1}\end{array}$ & $\begin{array}{c}\mathbf{R E} \\
2\end{array}$ & $\begin{array}{c}\text { H-T } \\
3\end{array}$ \\
\hline repGDP & $\begin{array}{l}0.611 \\
(1.52)\end{array}$ & $\begin{array}{l}0.600 \\
(1.48)\end{array}$ & $\begin{array}{l}0.609 \\
(1.56)\end{array}$ \\
\hline partGDP & $\begin{array}{c}0.560 * * * \\
(6.37)\end{array}$ & $\begin{array}{c}0.941 * * * \\
(34.59)\end{array}$ & $\begin{array}{c}0.573 * * * \\
(6.77)\end{array}$ \\
\hline repLand & $\begin{array}{c}-1.794 * \\
(1.85)\end{array}$ & $\begin{array}{c}-1.817^{*} \\
(1.86)\end{array}$ & $\begin{array}{c}-1.796^{*} \\
(1.91)\end{array}$ \\
\hline partLand & $\begin{array}{c}-0.296 \\
(1.64)\end{array}$ & $\begin{array}{l}0.037 \\
(0.81)\end{array}$ & $\begin{array}{c}-0.240 \\
(1.56)\end{array}$ \\
\hline dist & $\cdot$ & $\begin{array}{c}-1.582 * * * \\
(22.35)\end{array}$ & $\begin{array}{c}-3.838 * * * \\
(2.79)\end{array}$ \\
\hline EMU & $\begin{array}{l}-0.152 \\
(0.65)\end{array}$ & $\begin{array}{r}-0.165 \\
(0.71)\end{array}$ & $\begin{array}{r}-0.149 \\
(0.65)\end{array}$ \\
\hline CPEMU & $\begin{array}{l}0.071 \\
(0.39)\end{array}$ & $\begin{array}{l}0.058 \\
(0.32)\end{array}$ & $\begin{array}{l}0.072 \\
(0.40)\end{array}$ \\
\hline ERM2 & $\begin{array}{l}-0.054 \\
(0.20)\end{array}$ & $\begin{array}{l}-0.048 \\
(0.17)\end{array}$ & $\begin{array}{l}-0.052 \\
(0.19)\end{array}$ \\
\hline Exchange_sd & $\begin{array}{c}-0.654^{*} \\
(1.90) \\
\end{array}$ & $\begin{array}{l}-0.361 \\
(1.05) \\
\end{array}$ & $\begin{array}{c}-0.645^{*} \\
(1.97) \\
\end{array}$ \\
\hline $\begin{array}{l}\text { contig } \\
\text { repl_locked } \\
\text { partl_locked }\end{array}$ & 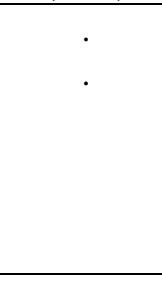 & $\begin{array}{c}0.023 \\
(0.06) \\
1.895 \\
(1.56) \\
-0.392 * * \\
(2.59) \\
\end{array}$ & $\begin{array}{c}12.224 \\
(0.62) \\
1.777 \\
(1.30) \\
-1.626^{* *} \\
(1.27) \\
\end{array}$ \\
\hline $\begin{array}{l}\text { Africa_EMU } \\
\text { part_CentralEurope }\end{array}$ & $\begin{array}{c}-0.848 * * * \\
(4.33) \\
.\end{array}$ & $\begin{array}{c}-0.989 * * * \\
(5.05) \\
0.358 \\
(1.00) \\
\end{array}$ & $\begin{array}{c}-0.848^{* * * *} \\
(4.44) \\
-9.142 \\
(1.21) \\
\end{array}$ \\
\hline GATT_WTO & $\begin{array}{c}0.291 * * * \\
(2.75)\end{array}$ & $\begin{array}{l}0.010 \\
(0.11)\end{array}$ & $\begin{array}{c}0.288 * * * \\
(2.79)\end{array}$ \\
\hline OECD & $\begin{array}{c}0.792 * * * \\
(5.89)\end{array}$ & $\begin{array}{c}0.693 * * * \\
(5.50)\end{array}$ & $\begin{array}{c}0.793 * * * \\
(6.06)\end{array}$ \\
\hline EU & $\begin{array}{c}0.312 * * * \\
(2.17)\end{array}$ & $\begin{array}{l}0.262^{*} \\
(1.84)\end{array}$ & $\begin{array}{c}0.309 * * \\
(2.21)\end{array}$ \\
\hline Europe_Agrmt & $\begin{array}{l}0.144 \\
(1.17)\end{array}$ & $\begin{array}{l}-0.007 \\
(0.06)\end{array}$ & $\begin{array}{l}0.143 \\
(1.19)\end{array}$ \\
\hline
\end{tabular}


Table 1 Continued

\begin{tabular}{|l|c|c|c|}
\hline Estimation & FE & RE & H-T \\
method & $\mathbf{1}$ & $\mathbf{2}$ & $\mathbf{3}$ \\
\hline \hline CEFTA & 0.276 & $0.322^{*}$ & $0.278^{*}$ \\
& $(1.64)$ & $(1.92)$ & $(1.69)$ \\
_cons & $-23.948^{* * *}$ & $-20.129^{* *}$ & 6.698 \\
& $(2.78)$ & $(2.47)$ & $(0.47)$ \\
\hline No. Of obs. & 4479 & 4479 & 4479 \\
No. Of groups & 317 & 317 & 317 \\
R2_overall & 368 & 795 & \\
R2_between & 414 & 885 & \\
R2_within & 259 & 254 & \\
\hline chi2 test for time effects & 10.31 & 62.62 & 90.78 \\
p- val & $(0.000)$ & $(0.000)$ & $(0.000)$ \\
\hline Hausman test & & & \\
\hline p- val & \multicolumn{3}{|l}{} \\
\hline
\end{tabular}

Source: own estimation.

In column (1) of Table 1 we present the estimates of the benchmark gravity equation estimated via the fixed effects estimator in which the dependent variable is defined as the $\log$ of bilateral exports. It turns out that the estimated coefficient on the EMU membership, our key explanatory variable describing the situation when both trading countries are the members of the $E M U$, is not statistically significant. Thus, participation in the EMU does expand trade of the new Eurozone member countries.

An important variable that turned out to be statistically significant at the 10 per cent level was Exchange_sd that measured the exchange rate volatility. The estimated parameter of this variable displayed a negative sign which means that the reduction in exchange rate volatility is associated with higher exports. This finding is also in line with the findings of previous studies that documented a negative impact of exchange rate volatility on trade. Therefore, we can expect that the elimination of exchange rate volatility as the result of the euro adoption will stimulate exports.

Moreover, our estimation results reveal a positive but not statistically significant coefficient on the CPEMU dummy variable. This variable indicates that the decision of some CEE countries to peg their local currencies to the euro did not contribute to the expansion of some Central European countries exports. This result is different from the results reported by Cieślik, Michałek and Mycielski (2009) for the broader sample of countries in the pre-crisis period for which the decision of some Central European countries 
to peg their local currencies to the euro has strongly contributed to the expansion of their exports. The contraction of trade within the Eurozone might have been responsible for this result. It also turned out that the ERM2 variable was not statistically significant.

The negative sign is reported in the case of the estimated parameter on the $A f r i c a \_t o \_E M U$ dummy variable which is statistically significant at the 1 per cent level. Thus, the decision of some African countries to peg their currencies to Euro has depressed their exports to Central European countries in the period covered by our sample.

The majority of the estimated parameters on the remaining explanatory variables derived from the trade theory and trade policy are statistically significant and display expected signs. Due to space constraints we do not go into details concerning the interpretation of all parameters as they serve as control variables here and our attention is focused mainly on the trade implications of the euro adoption. In particular, it is worth noting that the multilateral liberalization within GATT/WTO and OECD increased exports of CEE countries and other countries in our sample, as well. Also the EU membership contributed to the expansion of exports of the Central European countries.

The robustness of our benchmark estimates is investigated in the remaining columns of Table 1. In column (2) we estimate the same gravity equation for bilateral exports using the random effects estimator instead of the fixed effects. The estimation results obtained via the random effects look very similar to those obtained via the fixed effects. A major important difference is that the estimated parameter on the Exchange-sd variable loses its statistical significance when the random effects estimator is used. Moreover, the GATT-WTO variable lost its statistical significance while CEFTA became statistically significant at the 10 per cent level and displayed the positive sign. However, the Hausman test favored the use of fixed effects as the appropriate estimation format.

In column (3) we estimate the same equation for exports using the Hausman-Taylor estimator. However, the estimation results obtained while using this method do not differ much from the results obtained previously using the fixed and random effects estimators. The Hausman test favors the use of the Hausman-Taylor estimator over the fixed effects.

In Tables 2 and 3 we present the estimation results for the bilateral exports obtained separately for Slovakia and Slovenia. The particular columns of these tables are the direct counterparts of columns in Table 1. 
Table 2. Estimation Results for Slovakia

(t- and z-stats)

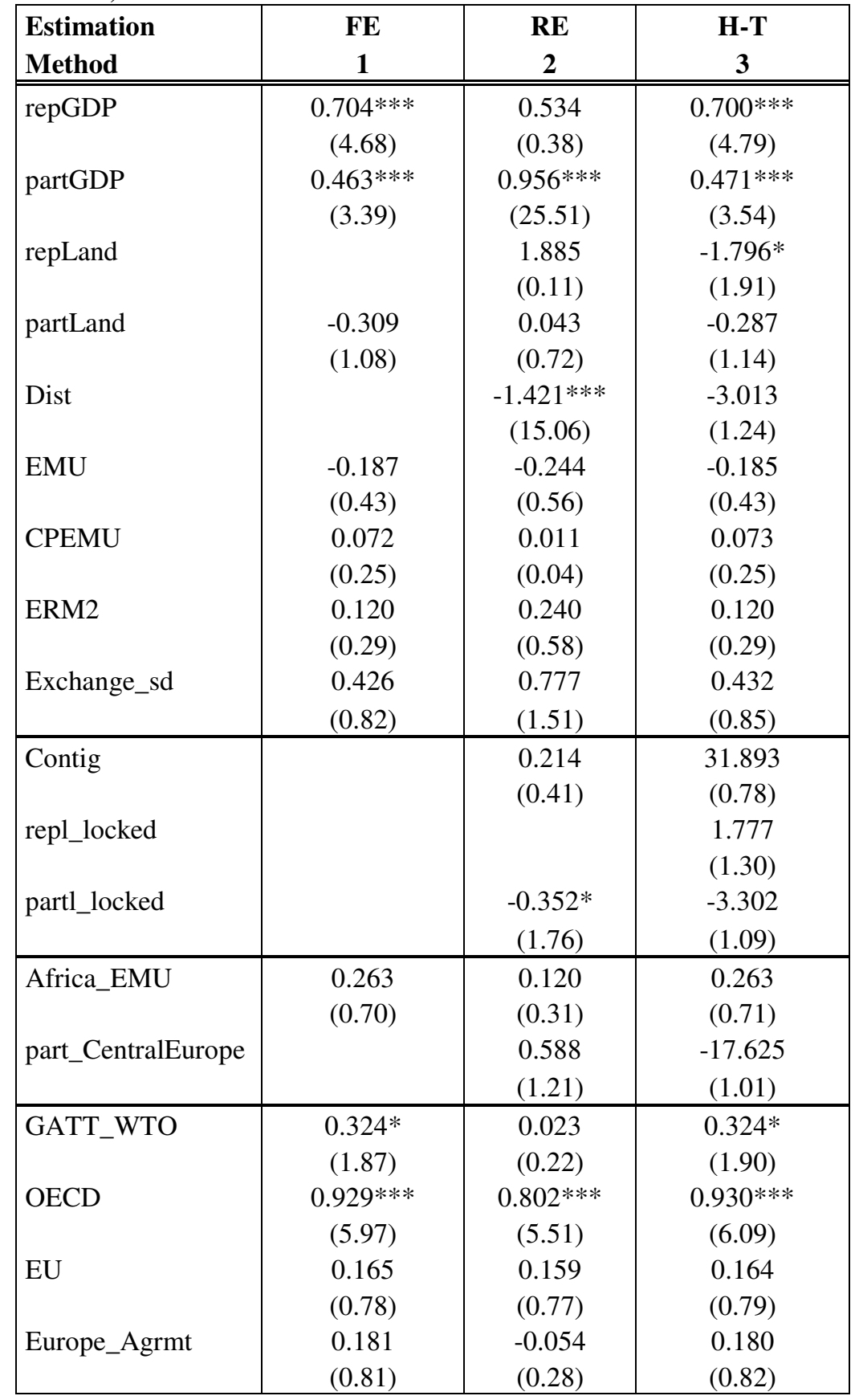


Table 2 Continued

\begin{tabular}{|l|c|c|c|}
\hline Estimation & FE & RE & H-T \\
Method & $\mathbf{1}$ & $\mathbf{2}$ & $\mathbf{3}$ \\
\hline \hline CEFTA & 0.335 & $0.451^{*}$ & 0.336 \\
& $(1.27)$ & $(1.74)$ & $(1.30)$ \\
_cons & $-21.143^{* * *}$ & -13.926 & 3.686 \\
& $(8.17)$ & $(1.02)$ & $(0.817)$ \\
\hline No. Of obs. & 2242 & 2242 & 2242 \\
No. Of groups & 159 & 159 & 159 \\
R2_overall & 489 & 786 & \\
R2_between & 584 & 889 & \\
R2_within & 289 & 283 & \\
\hline chi2 test for time & & & \\
effects & 8.02 & 42.70 & 73.04 \\
p- val & $(0.000)$ & $(0.000)$ & $(0.000)$ \\
\hline Hausman test & & & \\
\hline p- val & & & \\
\hline
\end{tabular}

Source: own estimation.

Table 3. Estimation Results for Slovenia

(t- and z-stats)

\begin{tabular}{|l|c|c|c|}
\hline Estimation & FE & RE & H-T \\
Method & $\mathbf{1}$ & $\mathbf{2}$ & $\mathbf{3}$ \\
\hline \hline repGDP & $0.292^{*}$ & 0.149 & $0.290^{*}$ \\
partGDP & $(1.88)$ & $(1.14)$ & $(1.95)$ \\
& $0.670^{* * *}$ & $0.926^{* * *}$ & $0.682^{* * *}$ \\
repLand & $(6.08)$ & $(24.09)$ & $(6.49)$ \\
& & & \\
partLand & & & -0.244 \\
Dist & -0.300 & 0.024 & $(1.26)$ \\
& $(1.35)$ & $(0.37)$ & $-3.715 * *$ \\
EMU & & $-1.757 * * *$ & $(2.22)$ \\
& & $(16.89)$ & -0.179 \\
CPEMU & -0.183 & -0.180 & $(0.65)$ \\
& $(0.64)$ & $(0.64)$ & 0.018 \\
& 0.017 & 0.030 & $(0.08)$ \\
\hline
\end{tabular}


Table 3 Continued

\begin{tabular}{|c|c|c|c|}
\hline $\begin{array}{l}\text { Estimation } \\
\text { Method } \\
\end{array}$ & $\begin{array}{c}\text { FE } \\
1 \\
\end{array}$ & $\begin{array}{c}\text { RE } \\
2 \\
\end{array}$ & $\begin{array}{c}\text { H-T } \\
3 \\
\end{array}$ \\
\hline $\begin{array}{l}\text { ERM2 } \\
\text { Exchange_sd }\end{array}$ & $\begin{array}{c}-0.193 \\
(0.53) \\
-1.927 * * * \\
(4.31) \\
\end{array}$ & $\begin{array}{c}-0.084 \\
(0.23) \\
-1.690 * * * \\
(3.80) \\
\end{array}$ & $\begin{array}{c}-0.189 \\
(0.53) \\
-1.916 * * * \\
(4.43) \\
\end{array}$ \\
\hline $\begin{array}{l}\text { Contig } \\
\text { repl_locked } \\
\text { partl_locked }\end{array}$ & & $\begin{array}{l}-0.301 \\
(0.51) \\
\end{array}$ & $\begin{array}{l}4.566 \\
(0.15) \\
1.777 \\
(1.30) \\
-0.906 \\
(0.60)\end{array}$ \\
\hline $\begin{array}{l}\text { Africa_EMU } \\
\text { part_CentralEurope }\end{array}$ & $\begin{array}{c}-1.346 * * * \\
(6.26) \\
. \\
.\end{array}$ & $\begin{array}{c}-1.471 * * * \\
(6.86) \\
0.112 \\
(0.22)\end{array}$ & $\begin{array}{c}-1.345 * * * \\
(6.46) \\
-5.392 \\
(0.56)\end{array}$ \\
\hline $\begin{array}{l}\text { GATT_WTO } \\
\text { OECD }\end{array}$ & $\begin{array}{c}0.277^{* * *} \\
(2.20)\end{array}$ & $\begin{array}{l}0.021 \\
(0.19)\end{array}$ & $\begin{array}{c}0.274 * * \\
(2.25) \\
0.930 * * * \\
(6.09)\end{array}$ \\
\hline $\mathrm{EU}$ & $\begin{array}{c}0.433 * * \\
(2.16)\end{array}$ & $\begin{array}{c}0.358 * \\
(1.79)\end{array}$ & $\begin{array}{c}0.430 * * \\
(2.21)\end{array}$ \\
\hline Europe_Agrmt & $\begin{array}{l}0.083 \\
(0.58)\end{array}$ & $\begin{array}{l}-0.002 \\
(0.01)\end{array}$ & $\begin{array}{l}0.081 \\
(0.60)\end{array}$ \\
\hline $\begin{array}{l}\text { CEFTA } \\
\text { _cons }\end{array}$ & $\begin{array}{c}0.178 \\
(0.84) \\
-15.791 * * * \\
(5.33) \\
\end{array}$ & $\begin{array}{l}0.185 * \\
(0.87) \\
-3.603 \\
(1.12) \\
\end{array}$ & $\begin{array}{l}0.178 \\
(0.87) \\
14.673 \\
(1.01) \\
\end{array}$ \\
\hline $\begin{array}{l}\text { No. Of obs. } \\
\text { No. Of groups } \\
\text { R2_overall } \\
\text { R2_between } \\
\text { R2_within }\end{array}$ & $\begin{array}{c}2237 \\
158 \\
491 \\
573 \\
247\end{array}$ & $\begin{array}{c}2237 \\
158 \\
809 \\
885 \\
243 \\
\end{array}$ & $\begin{array}{c}2237 \\
158\end{array}$ \\
\hline $\begin{array}{l}\text { chi2 test for time effects } \\
\text { p- val }\end{array}$ & $\begin{array}{c}13.52 \\
(0.000)\end{array}$ & $\begin{array}{c}30.95 \\
(0.000)\end{array}$ & $\begin{array}{c}45.82 \\
(0.000)\end{array}$ \\
\hline \multicolumn{4}{|l|}{ Hausman test } \\
\hline p- val & & & \\
\hline
\end{tabular}

Source: own estimation. 
The results obtained for two countries separately are very similar to the results obtained for the combined sample. In the case of both Slovenia and Slovakia participation in the Eurozone (EMU variable) did not have statistically significant impact on their exports. Similarly, the participation in the ERM2 did not affect exports of those countries. An important difference between Slovakia and Slovenia is, however, related to the volatility of exchange rate and the EU membership. The reduction in volatility significantly expanded Slovenian exports while it had no impact on the exports of Slovakia. Similarly, participation in the EU positively affected Slovenian exports and had no impact on the exports of Slovakia.

\section{CONCLUSIONS}

The main goal of this paper was to investigate the ex post trade effects of the euro adoption for two Central European countries: Slovakia and Slovenia using a modified gravity model that allows for incomplete specialization in production and controls for an extended set of trade theory and policy variables. The trade theory variables included both the country size and factor proportion variables. Trade policy variables included the membership in GATT/WTO, CEFTA, OECD, EU and Europe Agreements. The gravity model was estimated using the panel data approach on a sample of CEE countries trading with the rest of the world during the period 1992-2009 using the fixed effects, random effects and Hausman-Taylor estimators. It turned out that elimination of exchange rate volatility resulted in trade expansion for the CEE countries but the accession to the Eurozone did not have any significant effects on exports of Slovakia and Slovenia.

Therefore, our empirical results suggest that the research hypothesis stating that the accession to the Eurozone of two new EU member countries: Slovakia and Slovenia had a similar effect on trade as in the case of the Eurozone founding members is not valid. These results are in sharp contrast to the majority of studies analyzing ex post trade implications of the Eurozone membership for the old member countries which demonstrated that the participation in the Eurozone increased their trade. Moreover, these results are in contrast to the ex ante studies aiming at estimation of the euro adoption by the Central European EU member states.

These surprising results might be due to the financial and economic crisis of 2008-2009. Therefore, in future research our results should be verified for the longer period of time and a broader sample of the Central and Eastern European countries. 


\section{LITERATURE}

Aristovnik A., Meze M., (2009), The Economic and Monetary Union's Effect on (International) Trade: The Case of Slovenia Before Euro Adoption, "MPRA Paper" No. 17445.

Belke A., Spies, J. (2008), Enlarging EMU to the East: What Effects on Trade?, "Empirica", Vol. 35.

Berger H., Nitsch V. (2008), Zooming Out: The Trade Effect of the Euro in Historical Perspective, "Journal of International Money and Finance", Vol. 27.

Bergstrand J.H. (1990), The Heckscher-Ohlin-Samuelson Model, The Linder Hypothesis and the Determinants of Bilateral Intra-Industry Trade, "Economic Journal", Vol. 100.

Brouwer J., Paap P., and Viaene J-M., (2008), The Trade and FDI Effects of EMU Enlargement, "Journal of International Money and Finance", Vol. 27.

Bun, M. and Klaassen F., (2002), Has the Euro Increased Trade?, "Tinbergen Institute Discussion Paper", No. 02-108/2.

Cieślik A., (2009), Bilateral Trade Volumes, the Gravity Equation and Factor Proportions, "Journal of International Trade \& Economic Development", Vol. 18, No. 1.

Cieślik A., Michałek J.J., Mycielski J. (2009), Prognoza skutków handlowych przystapienia do Europejskiej Unii Monetarnej dla Polski przy użyciu uogólnionego modelu grawitacyjnego, "Bank i Kredyt", Vol. 40, No. 1.

Fidrmuc J., Huber J., Michałek J. (2001), Poland's Accession to the European Union: Demand for Protection of Selected Sensitive Products, "MOCT-MOST Economic Policy in Transitional Economies", Vol. 11.

Flam H., Nordstrom H. (2003), Trade Volume Effects of the Euro: Aggregate and Sector Estimates, Institute for International Economic Studies, unpublished.

Maliszewska M.A. (2004), New Member States Trading Potential Following EMU Accession: A Gravity Approach, "Studies and Analyses", No. 286, CASE - Center for Social and Economic Research.

Micco A., Stein E., Ordonez, G. (2003), The Currency Union Effect on Trade: Early Evidence from EMU, "Economic Policy", Vol. 18.

Rose A. (2000), One Money, One Market: Estimating the Effect of Common Currencies on Trade, "Economic Policy", Vol. 15.

Rose A. (2001), Currency Unions and Trade: The Effect is Large, "Economic Policy", Vol. 16.

Rose A.K., E. van Wincoop (2001), National Money as a Barrier to Trade: The Real Case for Monetary Union, “American Economic Review”, Vol. 91. 


\section{APPENDIX - LIST OF COUNTRIES IN THE SAMPLE}

Partners: countries with population over 200 thousand inhabitants

Albania, Algeria, Angola, Argentina, Armenia, Australia, Austria, Azerbaijan, Bahamas, Bahrain, Bangladesh, Barbados, Belarus, Belgium, Belize, Benin, Bhutan, Bolivia, Bosnia and Herzegovina, Botswana, Brazil, Brunei, Bulgaria, Burkina Faso, Burundi, Cambodia, Cameroon, Canada, Cape Verde, Central African Republic, Chad, Chile, China, Colombia, Comoros, Congo, Dem. Rep., Congo, Rep., Costa Rica, Cote d'Ivoire, Croatia, Cyprus, Czech Republic, Denmark, Djibouti, Dominican Republic, Ecuador, Egypt Arab Rep., El Salvador, Equatorial Guinea, Eritrea, Estonia, Ethiopia(excludes Eritrea), Fiji, Finland, France, Gabon, Gambia, Georgia, Germany, Ghana, Greece, Guatemala, Guinea, Guinea-Bissau, Guyana, Haiti, Honduras, Hungary, Iceland, India, Indonesia, Iran Islamic Rep., Iraq, Ireland, Israel, Italy, Jamaica, Japan, Jordan, Kazakhstan, Kenya, Korea, Rep., Kuwait, Kyrgyz Republic, Lao PDR, Latvia, Lebanon, Lesotho, Liberia, Libya, Lithuania, Luxembourg, Macedonia FYR, Madagascar, Malawi, Malaysia, Maldives, Mali, Malta, Mauritania, Mauritius, Mexico, Moldova, Mongolia, Morocco, Mozambique, Namibia, Nepal, Netherlands, New Zealand, Nicaragua, Niger, Nigeria, Norway, Oman, Pakistan, Panama, Papua New Guinea, Paraguay, Peru, Philippines, Poland, Portugal, Qatar, Romania, Russian Federation, Rwanda, Saudi Arabia, Senegal, Sierra Leone, Singapore, Slovak Republic, Solomon Islands, South Africa, Spain, Sri Lanka, Sudan, Suriname, Swaziland, Sweden, Switzerland, Syrian Arab Republic, Tajikistan, Tanzania, Thailand, Togo, Trinidad and Tobago, Tunisia, Turkey, Uganda, Ukraine, United Arab Emirates, United Kingdom, United States, Uruguay, Vanuatu, Venezuela, Vietnam, Yemen, Zambia, Zimbabwe. 
